\title{
Man - the light of the Universe
}

\author{
PhD. Mihai Sebastian STOIAN \\ $\mathrm{PhD}$. in Theological Studies at \\ 'Ovidius University' of Constanta \\ ROMANIA \\ E-mail: stoian.mihai55@yahoo.com
}

\begin{abstract}
Humans have studied and have been studying ceaselessly the universe, trying to find out our place in this mysterious cosmos, learning all the time something and as we believe that we have established something, there are other question marks to come. This is probably due to our inability to know everything. Science sometimes seeks and finds answers but not cease to be amazed, to bow before the mystery. However we must accept that there are countless ways to approach the differences between the possibilities of knowledge for understanding the universe.
\end{abstract}

Keywords: Universe; Man; Expansion; Atom; Time; Big Bang;

\section{INTRODUCTION}

Human beings since ancient times tried to chase away the specter of the unknown in their imaginations. Man needed to find his place in the hierarchy of creation and to relate to the cosmos, to the entire universe trying to avoid confrontation with the unknowable. But today science has to offer much more than simple hypotheses. The explanations of science must be quite deep regarding the cosmos. These explanations must give coherence and unity to a multitude of disparate facts.

Modern cosmologists based on the assumption that the laws governing the world here on earth are valid all over the universe. But in other circumstances of extreme density and temperature outside our planet, we come to some approximations that need to be adapted to the unusual conditions we encounter.

Cosmologists often talk about building "cosmological patterns". Through this means, generating simplified mathematical descriptions of the structure and the past of the universe, descriptions that seem to capture its main features. ${ }^{1}$

It is like using a layout to reproduce some of the characteristics of the real object in itself, but not all, in the same way a model of the universe cannot hope to cover every detail of the structure of the universe.

\section{Origin of the universe}

One of the most striking features of our universe is that its visible part is so well described by the simplified model of uniform distribution of the raw. Our cosmological patterns involve properties such as density or temperature. Their numerical values can only be found by observations, and only certain combinations of values observed for some of

\footnotetext{
${ }^{1}$ John D. Barrow, Originea Universului, trad. Alexandru David, Ed. Humanitas, București, 2007, p.11
} 
these quantities are compatible with the model. Therefore, the compatibility between the model and the real universe can be verified.

The certainty of philosophers and astronomers, until the beginning of the twentieth century, that space is absolutely fixed - an arena in which stars, planets and all other celestial bodies carry out their movement - underwent transformations during the 1920s: first under the impetus of the physicists who were probing the consequences of Einstein's theory on gravity and then under the impulse of observations made by astronomer Edwin Hubble on the light coming from distant galaxies stars.

\subsection{Hubble's Law - The Expansion of the Universe}

Hubble called for a simple wave property. If their source moves away from the receiver then the frequency that the waves are received decreases. The movement of the finger up and down in quiet water and observing the ridges of waves heading towards a random point on the surface of the water will make you understand this principle. Now move your finger away from that point and continue to make waves, they will get there with a lower frequency than the one with which they are emitted. Then move your finger to the reception point and the frequency will increase.

This property is characteristic of all waves. In the case of sound waves, it is responsible for changing the locomotive whistling tone or the siren of the police car that passes near you. The light is also a wave, and when its source moves away from the observer, the decrease in the frequency of the light waves translates into the fact that the visible light received appears more reddish. This is why the effect is called "redness". When the light source approaches the observer, the received frequency increases, the visible light becomes bluer and the effect is called "shifting towards the blue".

What Hubble had discovered was the expansion of the universe. ${ }^{2}$ In place of an unchanging arena in which we can look the local pursuit of planets and stars, he found that the universe is in a dynamic condition. It was the greatest discovery of the 20th century science and confirmed the predictions of the general theory of relativity regarding the universe: it cannot be static. In order to gain a simple picture you must imagine the strands of dust on the surface of a balloon that inflates. The balloon will expand and the strands of dust will be removed from each other but will not dilate in the same way ${ }^{3}$.

\subsection{The primordial atom}

In the 1930s, the Belgian priest and physicist Georges Le Maitre played an important role. His theory of the "primordial atom" was the forerunner of what is now known as the big bang. The most important steps were made in the late 1940s by George Gamow, a Russian émigré arrived in the United States, and two of his young students, Ralph Alpher and Robert Herman. They began to take seriously the possibility of applying the physics they knew to deduce what happened in the early stages of the universe expansion. They discovered an essential aspect: if the universe would be formed in a hot, dense state in a distant past, there should have been some radiation from this explosive beginning. More exactly, they realized that when the universe was a few minutes old it must have been hot enough to have nuclear reactions everywhere. Later, these remarkable observations would be confirmed by more in-depth research. ${ }^{5}$

\footnotetext{
2 Alexander Sharov, Igor Novikov, Edwin Hubble, The discoverer of the Big Bang Universe, Cambridge University Press, New York, 2005, p. 56.

${ }^{3}$ John Farrell, The day without yesterday, Thunder`s Mouth Press, New York, 2005, p. 35.

${ }^{4}$ John D. Barrow, Originea Universului, p. 25.

${ }^{5}$ John Farrell, The day without yesterday, p. 99.
} 


\section{The nature of time}

The true nature of time is a longstanding problem shrouded in mystery. Thinkers of many cultures have faced it for thousands of years. The issue is in the following terms: do we need to look at time as an immutable and transcendent background, a stage for the unfolding of events, or time is simply the events themselves - so if nothing happens, there is no time? The difference is very important because accepting the first hypothesis, we can talk about the creation of the universe over time. The alternative is to look at time as something that is born with the universe. There was no "ahead" of the beginning of the universe, because before the beginning there was no time. Our experience of day-to-day measures time in terms of strings of natural events which succeed: the oscillations of the pendulum in the gravitational field of the Earth, the shadow left by the Sun on a sundial as the Earth rotates or the vibrations of a cesium atom.

We can't talk about what "time" is, except in terms of how we measure it. Time is often defined by the way in which things are changing. If this approach is correct, there may be things totally out of the question about the nature of time. Newton's representation on the world has given time a transcendental status. Time simply passes inexorably and uniformly, unaffected by any kind of events and by the content of the universe. ${ }^{6}$ Einstein represented his time in a totally different way. Space geometry and the rate of time flow are determined by the material content of the universe. Our universe is one in which quantum uncertainties are small, which gives us an unambiguous sense of flow of "time" in our everyday life. The requirements of having a universe of ours - one that allows the existence of life - can be very restrictive, making our universe a special one among all the possible worlds. ${ }^{7}$

\section{The Light of the Divine Lamp}

The divine Revelation shows us that the material world has a beginning in the utterance of God's word "Let there be light" (Genesis 1: 3) and a purpose, an end forever full of the divine light: "And night shall be no more; and I have no need of lamplight or sunlight, because the Lord God will be their light, and they shall reign for ever and ever " (Revelation 22: 5).

The Deviation from God - Supreme Reason to the material world or to the unreal world of heathen idolatry has caused in human thinking, on the one hand, the accumulation of information, more and more about the sensible reality, structuring them into categories and concepts and so their relationship to logical, provable, and on the other hand the setting of taboos of certain "axioms" that will be completely unassailable, mostly related to the origins of the world and of things. So they sat the landmarks of the experience and human imagination in place of the Divine Revelation; ${ }^{8}$ the consequence is immediate: there is only what can be proven by man through a sensitive and repeatable experience. Knowledge would pass through the senses and would be the product only of human reason.

In this manner has raised the philosophies and science (secular, atheist) as a method of knowledge and description of the world and of the existence, exclusively through the

\footnotetext{
${ }^{6}$ Helge Kragh, Cosmology and Controversy, Princeton University Press, New Jersey, 1996, p. 74.

${ }^{7}$ John D. Barrow, Originea Universului, p. 110.

${ }^{8}$ P.Schaff \& H.Wace, Gregory of Nyssa - On the making of man, The Nicene and Post-Nicene Fathers, vol.5, Grand Rapids, W.B. Eerdman Publishing Company, p.388.
} 
senses and intellect, without any endeavor of faith in the Divine Revelation of the above senses. Losing the landmarks of the divine revelation, secularized culture continuously generated countless cosmological theologies, theory which, although partially seem to describe and model the reality, however, does not offer human satisfactory answers to the questions and his deep spiritual aspirations. ${ }^{9}$ The secularized man of today does not bow down to the divine Reason that he has almost completely deny, but only loves his own reason with his own creations and representations. But with all his effort to avoid confronting his deep aspirations towards eternal happiness and love, the secular man merely succeeds in constantly deceiving himself, spinning in a ghetto of passions, boring monotony and suicidal nihilism.

For the orthodox Christian, however, divine Revelation and human reasoning are not in opposition, but in a never-ending dialogue whereas human rationality and the reasons of things in the world have their beginning and support the existence in Divine Reason. That is why man's dialogue with God is a loving relationship, full of spiritual light, full of meaning, full of spiritual understanding, a relationship developed and enriched in the cosmic framework. The cosmos itself, the entire world, is continually filled with this spiritual light, it is continually transformed in the light of love between God and people. In the divinehuman community of the Church, at the Divine Liturgy, we are already experiencing this communion that is more and more full of light between God, men and the world, as a "mirroring" light of the age to come. ${ }^{10}$ The existence of the world and people therefore has a luminous meaning, a sense, an everlasting light reason that comes from their dynamic connection with God the "Father of the Light". The light of the world is the uncreated divine Logos. This rational and spiritual harmony of the world is beautifully depicted in its cosmological teaching by St. Maximus the Confessor. ${ }^{11}$

Besides divine revelation, the world and man lose their true value and meaning. The contemporary secularized culture as the expression of the peak of human pride tends to eliminate totally marks of God in the life and thinking of the man, putting in their place atheist landmarks. In the center of existence is no longer any God, not even the cosmos idolized, but only the man with his productions, meaning he went from the theocentrism and cosmocentrism to the apotheotic anthropocentrism. God brought man to existence, building him in his personal - communitarian way. But in this enactment of man not only commanded, but engaged in a loving dialogue with the man to whom he planted all the powers necessary for this divine fellowship: "by taking the Lord God dust from the ground, he made man and breathed Before him the breath of life, and he became the living being"(Genesis 2: 7). Human life consists of, so, in a communion ever more free and more conscious, tending to become face to face with God, the Giver of life.

\footnotetext{
${ }^{9}$ Lars Thunberg, Microcosmos and Mediator The Theological Antropology of Maximus the Confessor, 2nd edition, Chicago, La Salle, 1995, p. 52.

${ }^{10}$ Jean-Claude Larchet, La divinisation de l'homme selon Saint Maxime le Confesseur, Les éditions du Cerf, Paris, 1996, p.119.

${ }^{11}$ Hans Urs von Balthasar, Cosmic Liturgy, The Universe According to Maximus the Confessor, Ignatius Press, San Francisco, 2003, p. 146.
} 
According to St. Maximus, if the whole cosmos presents itself through the hierarchy, unity and diversity of its creatures, so wonderfully guided symphonically by the divine Providence, as a church, even more so, the man, as part and as a summary in the small of the whole creation reflects, in his own personal nature, his constitution and his ecclesial purpose: the body is like a nave, the soul as a hierarchy, and the mind as an altar, in which the doxological sacrifice brought to God is continually made. ${ }^{12}$ The cosmos is a Sacred Scripture; He:

\footnotetext{
"depicts the harmonious fabric of the universe as a book that has, as letters and syllables, the bodies which are distinguished and thickened by the encounter of many qualities, which are the first and closest to us, and as words, the general qualities that are more Far and thin. From these, by reading them, the Word (Reason) that wraps out and is contoured in them in an unspoken way". ${ }^{13}$
}

The whole cosmos, which consists of the seen and unseen, is man, and the man, which consists of soul and body, is the cosmos. For the intelligible ones have the purpose of the soul, as the soul has the same purpose as the intelligible ones. And the senses are the image of the body, as the body is the face of the senses. The intelligible are the soul of the sensible ones, and the sensitive ones the body of the intelligible. And as the soul is in the flesh, so the cosmos intelligible in the sensible. And the sensible cosmos is held together by the intelligible, as the body is held by the soul. And from both of them a single cosmos is formed, as well as from soul and body one man. ${ }^{14}$

\section{The order of the Cosmos}

Our universe is special: it seems to be in a condition unlikely of well-ordered, in which the pace of expansion is the same in all directions, with a high accuracy. It's like you find the children's bedrooms in perfect order - a situation very unlikely. So, there must be an explanation for the amazing isotropy of the expansion of the universe. ${ }^{15}$ Looking at one of the greatest scientists, Albert Einstein, we see that although he had inherited the traditional idea of a static universe, this does not mean that his predecessors have rejected the possibility of any change in the state of the universe.

Although the idea of universal expansion or shrinkage did not arise, there was much speculation that the universe might collapse into a state of increasingly disordered in which life would not be possible. This perspective has emerged from research into how heat can be used as a source of power. The Industrial Revolution brought with it many important advances in science and technology, of which the most important was the design and understanding of functioning machines with steam. This has led to the study of heat as a form of energy. It had become clear that energy was a product to be preserved. It could not be created nor destroyed, but only transformed from one form into another. But there was something else. Some forms of energy are more useful than others. The measure of their utility is a measure of the order of that form under which the energy appears: the more

\footnotetext{
${ }^{12}$ V. Karayiannis, Maxime le Confesseur: Essence et energies de Dieu, Theologie historique, Paris, 1993, p. 343.

${ }^{13}$ Jean-Claude Larchet, La divinisation de l'homme selon Saint Maxime le Confesseur, p. 114.

${ }^{14}$ V. Karayiannis, Maxime le Confesseur..., p. 362.

15 John Barrow, Joseph Silk, The Left Hand of Creation: The Origin and Evolution of the Universe, 2nd edition, Oxford University Press, New York, 1994, p. 32.
} 
disordered it is, the less useful. This clutter, which has become known as "entropy," seems to always grow in natural processes. At a certain level, there's no mystery here. Your office and children's bedroom seem to shift from a state of order to a mess - never the other way round. There are several ways for things to evolve from order to disorder rather than vice versa, so the first trend is what we see in practice. This idea has been kept with holiness in the famous "second law of thermodynamics", which states that entropy in a closed system never falls. ${ }^{16}$ The universe is still in an extremely orderly state, although it is expanding by increasing its entropy for fifteen billion years. It's a mystery. It would mean that the starting point of the universe was very orderly, so a very different state, probably governed by a great principle of symmetry or economy.

These ideas, however, have proved impossible to use to discover the principle, because we don't sufficiently know the structure of the universe to identify all the ways of manifestation of order and disorder within it. Our calculations on current entropy are therefore incomplete. ${ }^{17}$ The mission of cosmologists is to establish a history of the expansion of the universe - to find out how galaxies have been formed; Why they are piling up in swarms; Why expansion has the speed it has - and to explain the shape of the universe and the equilibrium between matter and radiation. ${ }^{18}$

\section{Humanity in the universe}

Man is subject to creative communion with other subjects in virtue of freedom, uniqueness, alterity, relativity, complementarity, conscience, responsibility and dignity that characterizes his personal existence. ${ }^{19}$ He represents God in creation, it is the living icon of Jesus Christ as a prototype and has a special blessing and mandate to be a standing vis-à-vis God, his partner of dialogue in the creation and at the same time His mirror. According to St. Basil in Hexaemeron's Commentary, "Beings are mirrors of the tremendous beauty," and that is why the holy Fathers of the Eastern Front urged us to "see the beauty of the Creator in the beauty of the creatures," which scientists also confronted. Apparently, renowned researcher Karl Linne, when examining a microscope in front of students, a myositis flower fell into ecstasy. The amazement and the joy on his face were indescribable. Asked by the students what happened, what he saw, he replied: "The footsteps of God's steps in this world," so His beauty and majesty.

The purpose of man is to be in a personal relationship, free of conscience and responsibility with God, with the world, with heaven and earth, to accomplish by grace participation, the being and at the same time to contribute through his work to the completion of creation by transforming it in the kingdom of God. ${ }^{20}$ The universe of man is heaven and earth and can't be reduced to a single dimension or "opening". The man created "in the image of God" (Genesis 1:27) is "capax Dei". ${ }^{21}$ The human being has a spiritual and personal existence not only purely biological. We must not forget that man, the one taken from the dust is the one who is asking permanently about itself and about nature, it has a

\footnotetext{
${ }^{16}$ Arieh Ben-Naim, Entropy and the Second Law: Interpretation and Miss-Interpretations, World Scientific Publishing, Singapore, 2012, p. 10.

${ }_{17}^{17}$ Guy Deutscher, The Entropy Crisis, World Scientific Publishing, Singapore, 2008, p. 8.

${ }_{18}$ John D. Barrow, Originea Universului, p. 47.

${ }^{19}$ Albert Einstein, The world as $i$ see it, The book Tree edition, San Diego, 2007, p. 24.

20 Adam Hamilton, The way: Walking in the Footsteps of Jesus, Large Print edition, Abingdon Press, Nashville, 2016, p. 187.

${ }^{21}$ Luigi Gioia, The Theological Epistemology of Augustine`s De Trinitate, Oxford University Press, New York, 2008, p. 106.
} 
reflexive thinking. By the fact that his body was taken up by God from the earth, it is bound by nature, so it is one of it, it is part of it. But at the same time, being taken from it by the creation of the image and the inspiration of life from God, he is above it, because God is present and works especially through him in His creation. He is still not perfect, he has not reached the divine likeness. Through the body now lives in history here and now, but through the spirit is projected to its future becoming beyond history, from eternity. His special position in nature lies precisely in the fact that he overcomes any reached level. And to understand him, you must always interpret him, again, only as projected in the future as the one who realizes or misses in history and through history his mission of deification. So man is the being who anticipates the future, gives meaning to the present precisely because he shares the future, he actually trains it and lives today from the perspective of tomorrow.

This ancient relationship with God as the source of existence actually forms the essence of religion and makes man capable of spirituality and emanate spirituality. Man will remain human only as long as it exudes spirituality, meaning it will relate vertically with God and not only with the horizontal world. ${ }^{22}$ Man is in relation to himself, to his surrounding nature, and to his fellow human beings, as brothers and sons of God. Man can't exist alone in the world. He is a person and the person is an existence in communion that relates to God, the fellow human being, and nature. The man isn't self-sufficient, not an individual. Even the concept of an atom or an individual is today shown to be divisible. The existence of the human person is together-existence and pro-existence, according to the model of divine communion. Today, also benefiting from the "increased lights" of science in the process of knowing, we do not know precisely what man is. Pilate shows us "Ecce Homo!" But it doesn't define it and doesn 't refer to a particular man.

Research and studies carried out on him, by philosophers, theologians and scientists in particular, seem to be endless, precisely because permanent self-attainment of the attained condition seems to be a characteristic of the human condition. From here you can see how hard it is to be human, and at the same time how beautiful it is and also remains a man of humanity. This isn't a matter of time, methods and techniques of investigation, and specialized apparatus to know the essence of man. His person isn't unknown yet, but it is a divine miracle and mystery, which has always made him and made man human. It relates to the "human condition" of the ontological status of the human person in the cosmos, the status God has given him by creation. This status, which implies a special position in the cosmos (creation), means primarily self-consciousness, freedom and responsibility. When we look at a man's face and wonder what he means, the only amazement and admiration is the "right" answer. Truly as a person man remains a mystery and also a miracle of God in creation. ${ }^{23}$

In an attempt to find out what man is, we can say that, on the one hand, as the essence of the tree is revealed in the fruit, and the fruit is already present in the seed, so, seeing the deeds of a man, his behavior and his work can be said: that he is a good man, a true man, a beautiful man, not a perfect man, a "superman", an angel, or that he could and should also

${ }^{22}$ Voltaire, God and Human Beings, translated by Michael Shreve, Prometheus Books edition, New York, 2010 , p. 153.

${ }^{23}$ Cristoph Schoenborn, Man, The Image of God, San Francisco, Ignatius Press, 2011, p.40. 
become good, true and beautiful, since from the moment of his conception in existence, in the image of God as a person is a man with a dynamic identity. He is perfect and not perfect, he is neither an angel nor a monster, and for this reason no man is irrecoverable in history. Neuroplasticity of the brain convinces us. And that is why man should become permanent through education, faith and love to behave and act as such. From the opera, so from his work, we can know something of his essence and not so much of himself as we cannot penetrate and especially because he is an artisan, and the face he wants to display in society is only a conventional mask or a social role, it has ontological consistency and must be approached from a soteriological and eschatological perspective. On the other hand, let us not forget that as the "pyramids" don't show the humanity, the genius and the goodness of the pharaoh, but rather a favorable conjuncture, and that history was not written as a Scripture, but as a court chronicle we shouldn't believe that only the grandiose works show the real people who are "more men than others" and that "only their lives would have the quality" and the others would mean "only an anonymous clay table" at the disposal of those who exercise the power, the mastery of science, or the talent to mold them at will. Good, true and beautiful people are not "the slopes that break the masts, leaving only the bare rocks and stones on the beach", but "molecules that make up the water" so necessary to life. So whenever we try to explain what man is, there is always an unexpected phenomenon that causes a change of perspective. In this sense, "Kierkegaard noticed that the genius of the person belongs to the great infinitely small, both unpredictable but essential". ${ }^{24}$

From little things, from their daily behavior, they can know the man is truly great, good, true and beautiful.

\section{CONCLUSIONS}

If we were to take into account the geo-physical phenomena that were the basis for the formation of the earth we could say that the idea that man would have regarding the genesis of the world would be that of a chaos and not to the formation of the cosmos, of a world subject to laws precisely arrayed. ${ }^{25} \mathrm{Also}$, the experience of the empirical world on which the primitive man had, it was without doubt that of permanence, in which alternations of extinction and return to the same state occur. That is why it is suggested that in order to conceive a beginning of the world was necessary a „detachment superior to the physical environment outdoors, as well as the power to contemplate that environment as an integral whole, going in time beyond personal memory, to its distant beginning prefigured." ${ }^{, 26}$ This, however, leads us to the question: how did man come to the idea of a creative beginning, especially as this concept suggests the notion of "event", which also implies the consciousness time flow? For us Christians, to this concept, people reached on the basis of a

\footnotetext{
${ }^{24}$ Dominique Beaufils, Pr. Boris Bobrinskoy, Pr. John Breck, Oliver Clement, Claude Hiffler, Pr. Ioannis Chryssavgis, Mitropolitul Meletios, Pr. Ignace Peckstadt, Pr. Jean Roberti, Bertrand Vergely, Bioetica şi Taina persoanei, Perspective ortodoxe, Editura Bizantină, București, 2006, p.46.

${ }^{25}$ Remus Rus, Concepția despre om în marile religii, în Glasul Bsericii, An XXXVII, Nr.7-8,1978, p. 734.

${ }^{26}$ Brandon S.G.F, Creation Legend of the Ancient Near East, Hodder and Stoughten, London, 1963, p. 3.
} 
primordial revelation. Researchers who ignore faith have embarked on other theories. Some say that more factors have contributed to the crystallization of the idea.

The most important of these factors was to achieve the immediate attention away from the reality here and now, and to obtain a mental perspective that includes past experience, as well as identifying a particular event that marks or produces a new existential situation. ${ }^{27}$

Generally, man is seen as a limit; a convergence between the empirical world and the transcendent world, or the seen and the unseen. As a consequence of its convergence condition, where two different realms meet, man is placed in a mediator position, is the only being with perspectives of detachment from the immediate condition and projection in the future.

\section{BIBLIOGRAPHY:}

[1] Adam Hamilton, The way: Walking in the Footsteps of Jesus, Large Print edition, Abingdon Press, Nashville, 2016.

[2] Albert Einstein, The world as i see it, The book Tree edition, San Diego, 2007.

[3] Arieh Ben-Naim, Entropy and the Second Law: Interpretation and Miss-Interpretations, World Scientific Publishing, Singapore, 2012.

[4] Alexander Sharov, Igor Novikov, Edwin Hubble, The discoverer of the Big Bang Universe, Cambridge University Press, New York, 2005.

[5] Brandon S.G.F, Time and Mankind, Hutchinson \& Co 1St. edition, London, 1951.

[6] Brandon S.G.F, Creation Legend of the Ancient Near East, Hodder and Stoughten, London, 1963.

[7] Cristoph Schoenborn, Man, The Image of God, San Francisco, Ignatius Press, 2011.

[8] Dominique Beaufils, Pr. Boris Bobrinskoy, Pr. John Breck, Oliver Clement, Claude Hiffler, Pr. Ioannis Chryssavgis, Mitropolitul Meletios, Pr. Ignace Peckstadt, Pr. Jean Roberti, Bertrand Vergely, Bioetica și Taina persoanei, Perspective ortodoxe, Editura Bizantină, București, 2006.

[9] Erwin Schrodinger, Ce este viața? Aspectul fizic al celulei vii și spirit și materie, trad. din lb. engleză V. Efimov, Ed. Politică, București, 1980.

[10] Guy Deutscher, The Entropy Crisis, World Scientific Publishing, Singapore, 2008.

[11] Hans Urs von Balthasar, Cosmic Liturgy, The Universe According to Maximus the Confessor, Ignatius Press, San Francisco, 2003.

[12] Helge Kragh, Cosmology and Controversy, Princeton University Press, New Jersey, 1996.

[13] John D. Barrow, Originea Universului, trad. Alexandru David, Ed. Humanitas, București, 2007.

[14] Jean-Claude Larchet, La divinisation de l'homme selon Saint Maxime le Confesseur, Les éditions du Cerf, Paris, 1996.

[15] John Barrow, Joseph Silk, The Left Hand of Creation: The Origin and Evolution of the Universe, 2nd edition, Oxford University Press, New York, 1994.

[16] John Farrell, The day without yesterday, Thunder`s Mouth Press, New York, 2005.

[17] Lars Thunberg, Microcosmos and Mediator The Theological Antropology of Maximus the Confessor, 2nd edition, Chicago, La Salle, 1995.

[18] P.Schaff \& H.Wace, Gregory of Nyssa - On the making of man, The Nicene and Post-Nicene Fathers, vol.5, W.B. Eerdman Publishing Company, Grand Rapids, 1994.

[19] Remus Rus, Concepția despre om în marile religii, în Glasul Bisericii, An XXXVII, Nr.7-8, 1978.

[20] Voltaire, God and Human Beings, translated by Michael Shreve, Prometheus Books edition, New York, 2010.

${ }^{27}$ Brandon S.G.F, Time and Mankind,Hutchinson \& Co, London, 1951 p. 15-16. 